\title{
The Mobile Woman: Getting Around during the 1630 Plague in Bologna
}

\author{
Natalie Massong ${ }^{1}$ \\ ${ }^{1}$ Analysis and Management of Cultural Heritage, IMT School for Advanced Studies, Lucca, Italy \\ E-mail: natalie.massong@imtlucca.it
}

\begin{abstract}
*
Legal proclamations show that during the 1630 plague outbreak in Bologna, Italy, women were required to remain quarantined in their homes for the duration of the epidemic while men remained mobile. However, primary texts and visual sources demonstrate that despite these legal restrictions, women remained active players in the fight against the plague by circumventing regulations. Significantly, women played a key role in sustaining the Bolognese economy, in particular by travelling to work in the silk industry. Moreover, while male doctors enjoyed special dispensations to avoid visiting the sick directly, female nurses left their homes to care for the daily needs of patients in the lazzaretto, the plague hospital.
\end{abstract}

Artworks and primary texts depict a mobile woman. They show women from the poorest of backgrounds who were compelled to move through the city's public spaces, remaining active in the street life of the plagued city. For instance, along with unlicensed women healers and nuns, prostitutes commonly volunteered for service in the plague hospitals. This required a brief shift in the social status of these women as they moved from their brothels to the pestilent walls of the lazzaretto. This paper will address the contribution that these resilient women made to maintaining the family economy and the significant positions women held in administering care, which have been overlooked in the scholarship. It will argue that by performing these essential activities, Bolognese women enjoyed an increase in physical but also social mobility, albeit short-lived.

Keywords: Mobility, confinement, female work, plague hospitals

The anonymous and unrefined image of Via San Mamolo con scena di peste del 1630, a horrifying scene of a plagueridden street in Bologna, joins a rare genre of images that offer visual clues of the lived experience of Italian early modern epidemics (Fig. 1). ${ }^{1}$ It is one of only two early modern representation of a Bolognese streetscape during a pandemic which shows mobile women. ${ }^{2}$ To the right of the allegory of Death, a woman walks with her staff towards the middle of the street, seemingly disengaged from the surrounding chaos. Beyond her, at the gallows near the center of the image, two women form an audience for a hanging. In contrast to the street goers, the other women in the image are depicted as would be expected, from their windows, watching the activities of men unfold from above.

\footnotetext{
* I would like to extend my gratitude to the librarians at the Biblioteca comunale dell'Archiginnasio in Bologna, and to Prof. Riccardo Olivito, Terry Rodgers, Estelle Kurier, Jesai Chantler and Brenda Mayhew for their guidance and support. All translations are my own unless stated otherwise.

${ }^{1}$ This painting is one of only two existing street scenes depicting the 1630-1 plague in Bologna, both similarly composed by anonymous painter(s) shortly after the events. This first image is Anonymous, Via S. Mamolo con scena di peste del 1630. Cassa di Risparmio di Bologna, c.1631, oil on canvas, (m. 0.705 x 0.87m) and is on permanent display in Palazzo Pepoli, Museo della Storia di Bologna. The second and larger oil on canvas $(1.30$ x $0.95 \mathrm{~m})$, c. 1631 resides in the Archivio di Stato di Bologna.

${ }^{2}$ This image joins an extremely small collection of Italian street scenes and an even smaller group of works that depict mobile women during early modern plague. The painting attributed to Luigi Baccio del Bianco, La peste a Firenze nel 1630, Museo della Misericordia in Florence, is the only existing depiction of the 1630-1 plague in Florence, as noted by Henderson (plate 3). There are at least three women in this image; Melchiorre Gherardini's etching of Milan during the epidemic, Piazza di S. Babila durante la peste del 1630, c. 1630, Pinacoteca Tosio Martinengo di Brescia, shows at least one woman in the street chaos. It is not until the plague of 1657 in Rome that Louis Rouhier illustrates an abundance of activities performed by women in the streets in his collection of prints.
} 
Images that illustrate the mobility of women in the time of plagues in Italy are few, perhaps because most often women were subjected to greater restrictions to their movements than men. Restrictions on the movement of noble women and confinement to the domestic space was commonplace in early modern Italy, while working class women were regularly found in the public spaces of their cities. However, during the plague of 1630, all Bolognese women were legally obligated to remain inside their homes for months, with constraints aimed specifically at women lasting for the duration of the epidemic from July 1630 until June 1631. These regulations have framed the dominant historical narrative in such a way as to ignore the mobility of women (Brighetti, Guerrini, Malpezzi et al.). Yet this image and textual sources demonstrates that despite the initial laws that confined them to their homes, women remained actively involved within their communities. Specifically, women of lower classes played key roles in sustaining the local economy and in supporting the well-being of the city as primary caregivers ${ }^{3}$ however, the majority of scholarship has placed women in a peripheral position, devaluing the significant contributions made by women during the epidemic (Brighetti, Guerrini, Malpezzi et al.). Moreover, the ways in which movement in the city was facilitated by the roles adopted by some women while other women were expected to be immobile has yet to be investigated.

The forced quarantining of healthy women within their domestic environments was commonly enacted as a precautionary measure during periods of early modern plague (Cohn 248, 281). As mentioned by Samuel Cohn, plague treatises from the late $16^{\text {th }}$ century reflected the perception that women were the "most susceptible and the plague's principal carriers" (246). Indeed, earlier epidemics in Italy had shown this to be true, as some cities recorded more deaths of women than men. ${ }^{4}$ Cohn has pointed out that the increased vulnerability in women may have been linked to higher instances of poverty (187). The $1630-1$ plague in Bologna had an estimated total loss of $24 \%$ of the population with similar losses across both genders (Bellettini 41). Regardless, the female body, which was itself treated as a site of contagion, became a primary target of public policy.

As noted by historian Leigh Ann Whaley, early modern medicine was grounded in classical philosophical treatises that formed a framework for Renaissance understanding of the female body (48). These pervasive theories largely came from Galen, Aristotle and the Hippocratic Corpus, a group of medical treatises by multiple authors, which characterized women as "abnormal in comparison to the normal male,"

\footnotetext{
${ }^{3}$ On the economic impact of plague, see Giusberti and Roversi Monaco.
}

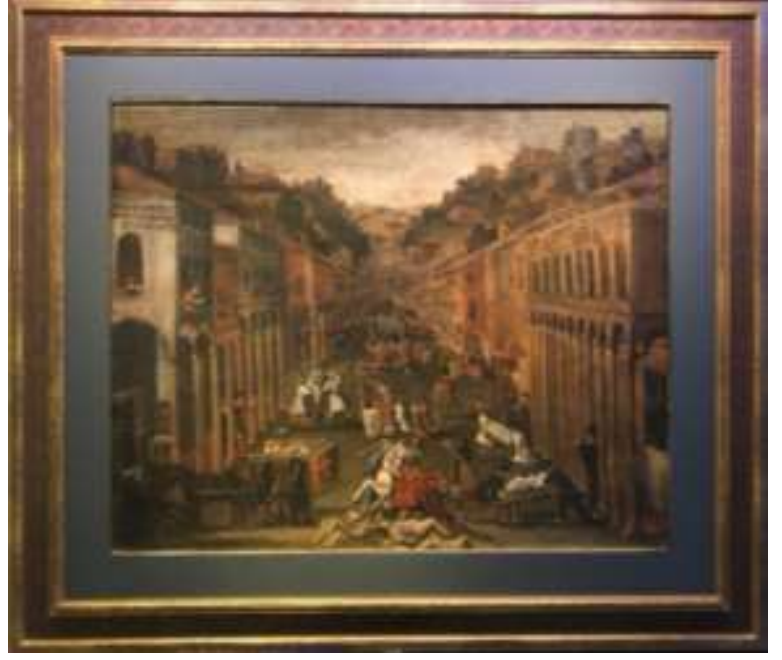

Figure 1 Anonymous, Via S. Mamolo con scena di peste del 1630, c.1630, oil on canvas, (0.705 x 0.87m), Cassa di Risparmio di Bologna, Palazzo Pepoli, Museo della Storia di Bologna. (Photographed by author.)
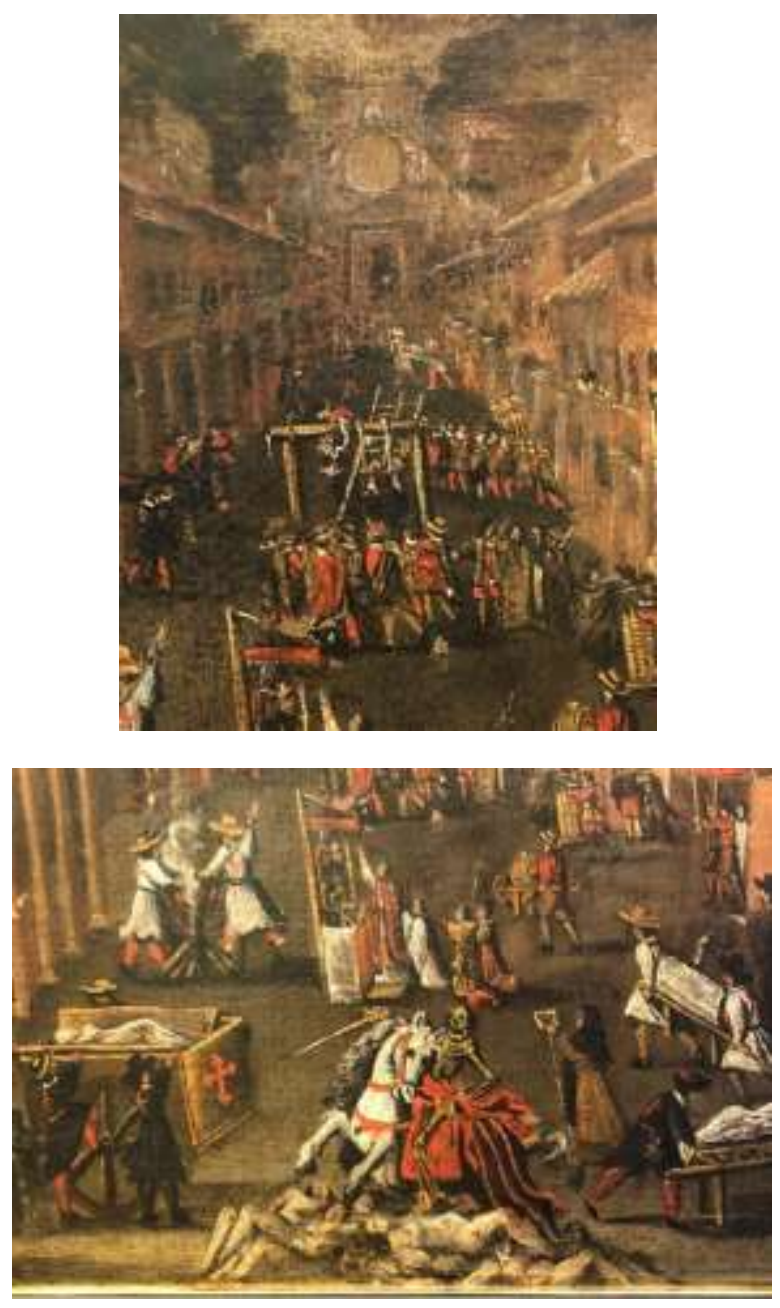

Details of Fig. 1

${ }^{4}$ Cohn has demonstrated that during plague outbreaks in Milan from the $15^{\text {th }}$ to $16^{\text {th }}$ centuries, more women than men died (222). 
necessitating "special treatment" for their inferior bodies, notions that remained ubiquitous in the Renaissance (49).

Health policy created during the $1630-1$ plague echoed these attitudes with regulations disproportionately directed at women. ${ }^{5}$ Confinement into the domestic space was a part of a process in which women were identified, classified, divided and imprisoned by the health authorities because of their classification as "abnormal." However, the division of all women into one category did not represent the real need of the healthcare system or the local economy. Exceptions to the overarching rule were quickly created which necessitated new ways of partitioning women set within a hierarchy, creating divisions based on class and occupation, each with varying access to mobility.

Geographer Doreen Massey, whose work has significantly contributed to the field of feminist geography and to our understanding of gendered space, argued in Space, Place, and Gender that "degrees of mobility" are gendered, in which women and men access, move through, and respond to spaces differently depending on their gendered experience (186). ${ }^{6}$ Moreover, Massey contends that distinct sections of society experience "differentiated mobility" according to their access to mobility, influenced by social status and wealth (149). While early modern women experienced varying levels of mobility under normal circumstances, during periods of epidemics, female mobility became contingent on being placed outside the category of "woman" into new classifications based on occupation and social status. "Woman" was substituted for new divisions such as, caldirane, infermiera, barbiera, gentildonna, ${ }^{7}$ and $e x$ prostitute, each with differing access to mobility. This article aims to demonstrate how entering these new categories afforded women the agency to maintain their household economy and temporarily overcome social and physical barriers, demonstrating great resilience in moments of crisis.

This article seeks to examine how social status and work activities facilitated female mobility through a

\footnotetext{
${ }^{5}$ Bando di divieto alle donne e ai bambini di uscire di casa per quindici giorni, pubblicato a Bologna il 25 luglio 1630 (Malpezzi et al. 96). The impact of the plague on children, for which there is limited documentation, has yet to be addressed.

${ }^{6}$ The use of gender here is understood as the biological differences between men and women that influence power relations, a definition that is most closely aligned with $17^{\text {th }}$ perceptions of gender. I acknowledge that gender is not binary, that these differences are perceived, and are socially and culturally driven.

${ }^{7}$ Caldirane were employees of the silk industry who worked with caldiere, cauldrons, used in the reeling process (Poni, "Misura contro misura" 385 , note 3 ). Infermiera (nurse), barbiera (female barber surgeon), gentildonna (noblewoman). As a general source of $16^{\text {th }}$ century occupations see, Garzoni.
}

collection of contemporary textual sources. In particular, Libro di dare, et avere, a seventeenth-century assemblage of original letters and accounts produced by the director of the lazzaretti, Padre Orimbelli, offers unique insight into the variety of roles adopted by women during the plague months. Letters documenting the activities of officials from the 16301 epidemic in Bologna, normally residing in the Vatican Apostolic Archive, but transcribed by Antonio Brighetti, provide contemporary knowledge on the experience of women. Finally, Pietro Moratti’s 1631 chronical, and Girolamo Donini's 1631 compilation of the legal notifications printed during the plague years, a work that has recently been translated into modern Italian, ${ }^{8}$ present the social complexities of female work. In the absence of visual records, these textual sources provide the foundations in which to examine how women experienced degrees of mobility during the epidemic.

The impact of plague on women has more broadly been addressed in scholarship encompassing history of healthcare. The critical contributions made by women to early modern healthcare in Northern Italy has been widely acknowledged. ${ }^{9}$ The significant body of work by John Henderson has extensively documented the impact of plague in 1630-1 Florence, including the changing status of marginalised groups, such as prostitutes, along with the role that women took in caring for the sick in the lazzaretti, plague hospitals. ${ }^{10}$ Scholarship on women within the context of plague hospitals has been considered by Jane Stevens Crawshaw in her important work on Venetian lazzaretti (plague hospitals). Additionally, Nicholas Terpstra has analysed the impact of plague and famine on women and the poor in Florence in Cultures of Charity. The roles that women acquired within plague hospitals and convalescent homes in Bologna have only briefly been recorded (Brighetti, Malpezzi et al.). Beyond healthcare, the activities of women during epidemics have received little attention in the scholarship. The general involvement of women in the silk industry of Bologna has been considered, ${ }^{11}$ although a deeper analysis of this female work during epidemics merits further examination. These

\footnotetext{
${ }^{8}$ For the purpose of clarity, I have used the modern Italian translation by Malpezzi et al. (2008).

${ }^{9}$ Pomata 119-43; Pomata and Foy; Stevens Crawshaw, "Families, Medical Secrets and Public Health in Early Modern Venice;" Strocchia; and Whaley.

${ }^{10}$ See Henderson Chapter 7 for women who worked in the lazzaretti and Chapter 8 for a discussion on prostitutes. I have chosen to use the modern Italian spelling of lazzaretto (singular) \& lazzaretti (plural) that is most commonly found in Italian scholarship.

${ }^{11}$ Terpstra; Poni, “All'origine del sistema di fabbrica;” Franceschi Righi; Arbizzani; and Tosi Brandi.
} 
studies offer a useful starting point in which to analyse how many women had agency that permitted physical movement and social mobility, despite most women experiencing lengthy enclosures.

The following section of this article exposes the immense measures taken by the Bolognese government to restrict the mobility of healthy women as demonstrated through the legal decrees, known as bandi, which would have been posted in public places in the territory. The second part will address how the movement of women was differentiated according to social standing. The last sections will use valuable primary resources in consideration of the fundamental work of women in the silk industry and in the lazzaretti, occupational roles that awarded various degrees of mobility that otherwise would not have been possible.

\section{The Great Enclosure}

As cases of plague increased across Bologna in the summer of 1630, new restrictions announced throughout the end of July were executed by the Bolognese Senate and the Papal Legate of Bologna, Cardinal Spada, to counter the growing wake of the epidemic. The government sought to block trade with other cities and limit the amount of people interacting in the streets in order to reduce the spread, soon directing their attention towards women and children. Bolognese law mandated that all those who were sick or suspected of illness were to be locked inside their homes, regardless of sex or social status, thus reducing the spread of the contagion. But public policy went further to specifically target healthy women, excluding them from public space, using disciplinary measures to control their mobility even in the absence of illness, as demonstrated by numerous edicts published in 1630-1 that will be examined in this section. ${ }^{12}$

Published on the $25^{\text {th }}$ of July 1630 the edict, Bando di divieto alle donne e ai bambini di uscire di casa per quindici giorni, pubblicato a Bologna il 25 luglio 1630 prohibited women and children under thirteen from leaving the house for fifteen days from the $27^{\text {th }}$ of July following government

\footnotetext{
${ }^{12}$ For instance, Bando di divieto alle donne e ai bambini di uscire di casa per quindici giorni, pubblicato a Bologna il 25 luglio 1630 (Malpezzi, et al. 94).

${ }^{13}$ The following bandi outlining the quarantine for women and children were renewed consecutively every ten to fifteen days after the original publication: Proroga della clausura alle donne a ai bambini, 10th of August, 1630; Seconda proroga della clausura delle donne e dei bambini. Dichiarazione per chi si muove in carrozza, 20th of August 1630; Terza proroga della clausura delle donne e dei bambini e dichiarazione per chi si muove in carrozza, 2nd of September, 1630; Proroga della clausura delle donne e dei bambini, 15 September, 1630, outlined that the quarantine was
}

guidelines (Malpezzi, et al. 94). This multi-page notification was the first bando (edict) which outlined the extensive restrictions that would limit the movement of women until the $14^{\text {th }}$ of June 1631 . It is the most important edict as it was republished consecutively from July 1630 until January $1631,{ }^{13}$ and legally obliged women and children to domestic confinement for the duration of the pandemic, with few exemptions made for the holidays around Christmas. ${ }^{14}$

This first bando, repeated until January, highlights how the law disproportionately impacted women, containing them in their homes for the entirety of the epidemic, prohibiting women from travelling to work or engaging in business. The bando describes that "especially those who by age or nature can more easily run into the danger of contagion, that is children and women, who are sick in much greater numbers than men" (Malpezzi et al 94). ${ }^{15}$ The justification of locking up women in their homes was that women, along with children, were more prone than men to contracting the plague, by reason of their age and by their natural disposition. Women and children were perceived as necessitating guardianship as the bando author writes, "the presence of women and children on the streets is little necessary and very dangerous for families, has decided to suspend for a few days the trade and the exiting of both" (94, my translation). ${ }^{16}$ Even though many women engaged in business activities and worked for the major industries of Bologna, their presence in public spaces was now considered inessential and dangerous for the family. Moreover, the bando reads that since their presence was not necessary, then their ability to conduct their trades outside the home should be stopped along with their right to leave their homes. This shows that female trade was specifically targeted while men could continue to operate their business from outside the home.

Exemptions to these laws applied to lower class women from the countryside who sold food or herbs, provided that their home had been without illness for one month, and that they were in possession of a fede di sanità, or simply fede, a

deemed effective until further notice (Malpezzi et al. 109, 112, 123, 127).

${ }^{14}$ Notifica per le donne e i bambini, 23rd of December 1630 (Malpezzi et al. 138).

15 "Specialmente di quelle che per età o per natura possono più facilmente incorrere nel pericolo di contagio, cioè i bambini e le donne, i quali sono ammalati in numero assai maggiore rispetto agli uomini" (Malpezzi et al. 94).

16 "La presenze delle donne e dei bambini per le strade è poco necessaria e molto pericolosa per le famiglie, ha deciso di sospendere per qualche giorno il commercio e l'uscita degli uni e delle atre" (Malpezzi et al. 94). 
certificate of health testifying to their good health. ${ }^{17}$ While they could enter the city, these women were prohibited to enter any home or tavern and were not allowed to remain overnight. A penalty of two-month prison sentence or being sent to work in the lazzaretto was threatened. Furthermore, these peasant women were not permitted to speak with their padrona, instead their mistress could send a man to negotiate with the peasant woman on her behalf (96). These laws put constraints on women who conducted business, as the manageress was prohibited from meeting her employees and vice versa.

In comparison, men could continue to operate their businesses unless they were found to be within a household suspected of plague (Malpezzi et al. 89). All peasants and farmers from the countryside, regardless of sex, who needed to enter the city to trade were required to obtain a fede in order to enter Bologna, ${ }^{18}$ as they were considered more likely to spread the plague because they were less "prudenti" (prudent) than city dwellers (113). The transferring of goods from outside the city without a licence was prohibited, although movement within the city was allowed for men (82). In contrast, all women and children required a licence in order to travel, which could be gained only if their home had been clear of contagion for forty days. Midwives could visit their patients with a special licence to travel (97).

The cost of not abiding by these laws was great, as women, children, and the men who were responsible for them under the law, were subject to penalties ranging from fines and corporeal punishment to forced labour in the lazzaretti. The July 1630 bando also indicated that penalties were assigned within a hierarchy, according to sex but also social position. The government had specific penalties according to the "qualità delle persone" (quality of the people), so that people of higher social standing received reduced sentences (95).

The sovereignty over women's bodies occurred within a hierarchy of control starting with the health authorities at the government level. At the parish level, a new position was established for men who would be responsible for the "control of enclosure for women and children" in their area (Ibid). Within the family itself, men were responsible for the behaviour of the women under their care and were charged with reporting infractions up the chain of command. Women without men to care for them were required to remain in the house but would be monitored and receive assistance from the health officials of their parish (Ibid).

\footnotetext{
${ }^{17}$ The fede di sanità had to be signed by three health officials (Malpezzi et al. 96).

${ }^{18}$ An example of these certificates has been reproduced from Donini in Malpezzi et al. (119).
}

Limitations to female mobility were continually enforced from January until June 1631, although access to most of the city was permitted in stages. At the beginning of January, women and children were allowed to leave the house on Sundays and on religious holidays to attend mass while remaining within their parish (145). While women were permitted more freedom, the administrative boundaries of the parish served as barriers for containment within the community. Edicts released by the end of January, and republished consecutively until June 1631, allowed women and children to travel around the city $(148,149,154,157$, $159,161-63)$. This was assuming they and their household had been clear of illness for forty days, and that they remained outside the areas defined as contagious.

There is some disagreement if men experienced a period of enclosure, as well. According to historians Carlo Cipolla, as well as Malpezzi et al., a general quarantine was called for the beginning of September 1630, which would have also confined men to their homes (Cipolla 99, note 3; Malpezzi et al. 233), although none of these authors provide textual evidence for their claim. While textual sources show that a general quarantine was considered and promoted by health officials, ${ }^{19}$ primary sources do not confirm whether healthy men were in fact quarantined as was the case for women. The edicts, published in August and September, never set out guidelines for restrictions on male movement, except for travel outside the city walls, rather they set out measures for "anticipation of general quarantine" (Malpezzi et al. 126). These edicts reflect the attempts of the government to finance the plague efforts, urging that since it is "approaching the time" of general quarantine, that citizens give alms (107). Another bando similarly implores its readers to collect provisions noting that the "general quarantine is forseen, making it necessary to accumulate money and supplies" (109). It is more likely that a general quarantine was planned but never enacted due to a positive turn in the epidemic from October (Bellettini 41). Men and women experienced a very different plague simply because of their diverse access to mobility.

The experience of women in domestic confinement was challenging, especially for those in impoverished conditions. Upon entering quarantine, women were confronted with severe pressure to provide for the basic needs of their households. The troubling reality of confinement was expressed in a report of concerns by neighbourhood representatives from the quarter of San Pietro Maggiore. They argued to end the quarantine noting that the prolonged

\footnotetext{
19 Anonymous, Archivio Segreto Vaticano (A.S.V.), Bologna, 282, ff. 108-09, cited in Brighetti 238-41; Anonymous, A.S.V., Bologna, 282, ff. 110-11, cited in Brighetti 241-44.
} 
enclosure of women and children and a lack of proper resources for subsistence was causing exhaustion and resulting in "molte infermità" (many illnesses). ${ }^{20}$ Another report expresses the difficulty in providing food to women and children because the lengthy period of enclosure had exhausted the alms already given by citizens. ${ }^{21}$ The bando, Polizza per distribuire il pane alle parrocchie per sovvenire alle necessità dei poveri in particolare delle povere donne rinchiuse Luglio 1630 addressed the need of getting basic resources to the poor, and specifically poor women who were in their first month of mandatory confinement (Malpezzi et al. 97). Despite plague specific taxation, ${ }^{22}$ there were legitimate fears that the economic constraints put on those in quarantine would have an impact on the long-term health of the individuals, in particular the poor, without means to survive. $^{23}$

When possible, women supported their household economies by transferring work normally conducted in public spaces to the home. The government made provisions for women to engage in the commercial activities of the silk and wool industries, the most important in the city, by assigning responsibility to parish health officials to bring work to the women confined in their homes (Malpezzi et al. 95-96). These poorer women were the very few who continued to bring in income. The inequalities of mobility experienced by women was layered, dependent not only on their gender but on their wealth and social status, as is evident with differing access to carriages.

\section{Social Inequities to Mobility: Women who Travel by Carriage}

The disparities in access to mobility is most clear when addressing the ways that a woman was able to travel by avoiding the streets prohibited to her during the plague. The carriage, an enclosed space that provided barriers from the putrid airs of the disease, was conceptualized as a safe space from which one could not catch the contagion. Its elevation from the street and the ability to move through the city at a rapid pace, provided a justification for the continued use of carriage.

The previously mentioned edict which addressed the quarantine measures in place from the $27^{\text {th }}$ of July 1630 ,

\footnotetext{
${ }^{20}$ Anonymous, A.S.V., Bologna, 282, ff. 109, cited in Brighetti 240.

${ }^{21}$ Ibid., 239.

22 Pietro Iachomo, A.S.V., Bologna, 282, f. 121 r., cited in Brighetti 294.

${ }^{23}$ Anonymous, A.S.V., Bologna, 282, ff. 109, cited in Brighetti 239; Anonymous, A.S.V., Bologna, 282, ff. 110, cited in Brighetti 242.
}

Bando di divieto alle donne e ai bambini di uscire di casa per quindici giorni, pubblicato a Bologna il 25 luglio 1630 (Malpezzi et al. 94-97) prohibited women and children travelling away from the home but did not extend to those who travelled by carriage, provided they resided in a home that had been free of plague for one month (96). Following this bando, the edict Seconda proroga della clausura delle donne e dei bambini. Dichiarazione per chi si muove in carrozza, published on $20^{\text {th }}$ of August 1630 and enforced until December, states that women and children could go around the city by carriage and women could be accompanied by a lady's maid, as long as they do not stop or go to church or meet with others. ${ }^{24}$

All women, including gentlewomen, were still expected to abide by the quarantine rules; however, women experienced differentiated mobility with major disparities in access to mobility (Massey 149). The financial capacity to own a carriage would have been reserved for wealthier citizens. Hiring a carriage was more feasible although out of reach for a large portion of the populace, who could only afford to travel by foot. Further to this, prostitutes were prohibited to travel by carriage (Malpezzi et al. 96), demonstrating how the laws specifically targeted marginalised groups of women.

The restrictions on women and children travelling by carriage were maintained into the autumn despite a drop in plague cases. Surprisingly, the rules tightened around the mobility of women in December, even though numbers had decreased. Bando sull'andare in carrozza delle donne e dei bambini, durante il periodo del contagio, describing the restriction on carriage travel for women and children during the period of contagion, released on the $8^{\text {th }}$ of December 1630 , reiterates the danger of women travelling to public spaces in the city, and revokes any licences that previously permitted women to travel by carriage, with the exception of food retailers and midwives. The law specifically targeted women of middle and working class, those who could afford travel by carriage but did not fall into the category of noblewomen. In fact, the new rules included further omissions for gentildonne. Under the new law, gentlewomen maintained their privilege to travel in carriages, along with their daughters, but now they were permitted to ride with a companion from another household. Moreover, these noble women were allowed to travel with several other aristocratic

\footnotetext{
24 "Second extension of the cloister of women and children. Declaration for those who travel by carriage" (Malpezzi, et al. 112). These stipulatations are repeated in Terza proroga della clausura delle donne e dei bambini e dichiarazione per chi si muove in carrozza -2 settembre 1630 (Malpezzi et al. 123).
} 
women, from different dwellings, in the same carriage along with companions and servants, thus experiencing an increase in mobility (Malpezzi et al. 136).

Women formally permitted to travel by carriage were positioned into a new category for exclusion with new disciplinary measures. Carriage drivers could lose their carriage and horses if they disobeyed the law, while the female traveler would endure corporal punishment (Ibid). The connotation of these laws is clear, women of different social standing had varying legal rights to mobility and, as a consequence, the threat of disciplinary action impacted women according to their social position. The edict is exemplary of the attitudes towards those outside the upper classes, as the body of the noble woman is understood to be less likely to transmit disease, while all women outside essential services are further controlled. The noble body is offered more legal rights to move through the city during a pandemic, while all other women in fact lose the last means of efficient mobility provided by the carriage. The bando also demonstrates that the perceived cleanliness of the noble female body extended to her chosen female companions, even those who lived outside her household. The aristocratic body carried an elite social and legal status, but also a physical superiority that could be transferred to others. While these specific exclusions to confinement only benefited elite women, alternative types of mobility were experienced exclusively by women who worked in the Silk Arts.

\section{Women and Work: The Silk Arts and its caldirane}

The silk industry went further than keeping women working within the domestic space; they managed to lobby for female workers to continue to work outside of the home. Bologna was a prominent actor in the silk industry of Europe during the early modern period in part due to its hydraulic powered torcitoio circolare, a silk throwing machine exclusive to Bologna from the fourteenth- until the sixteenthcentury (Giusberti and Monaco 167). Its famous hydraulic mills and unique methods of production placed the city in a dominant position in the European silk market (Terpstra 172). The nature of the hydraulic powered machines reduced hard labour, providing more employment for women (Poni, “All'origine del sistema" 475).

The production of silk was concentrated in the spring and summer months, according to the lifecycle of the silk worm (Terpstra 172). The level of production during those months necessitated seasonal labour, and according to 1587 estimates, the silk industry employed one third of the city's population during that period (Ibid). ${ }^{25}$ Out of approximately 25,000 workers, $84 \%$ were women (Poni, "Tecnologie"; Terpstra 323, cited in Giusberti and Monaco 173). A higher number of women than men were involved in the initial phases of production, from silk cocoons to the production of thread in preparation for weaving, while men were employed as the higher salaried expert weavers (Giusberti and Monaco 172). Women employed as caldirane worked with the caldiere, or cauldrons, large pots or vessels made of lead used in the reeling process (Tosi Brandi 305).

Reeling consisted of soaking the cocoon in a hot bath, loosening the fibres allowing for the delicate unravelling of the singular filament into skeins of thread (Giusberti and Monaco 167). The skeins went through a process called throwing, which involved the twisting of the skeins using the hydraulic powered torcitoio circolare machines (Franceschi 106). This aspect of the production could not be conducted at home and necessitated women to travel to the silk mills.
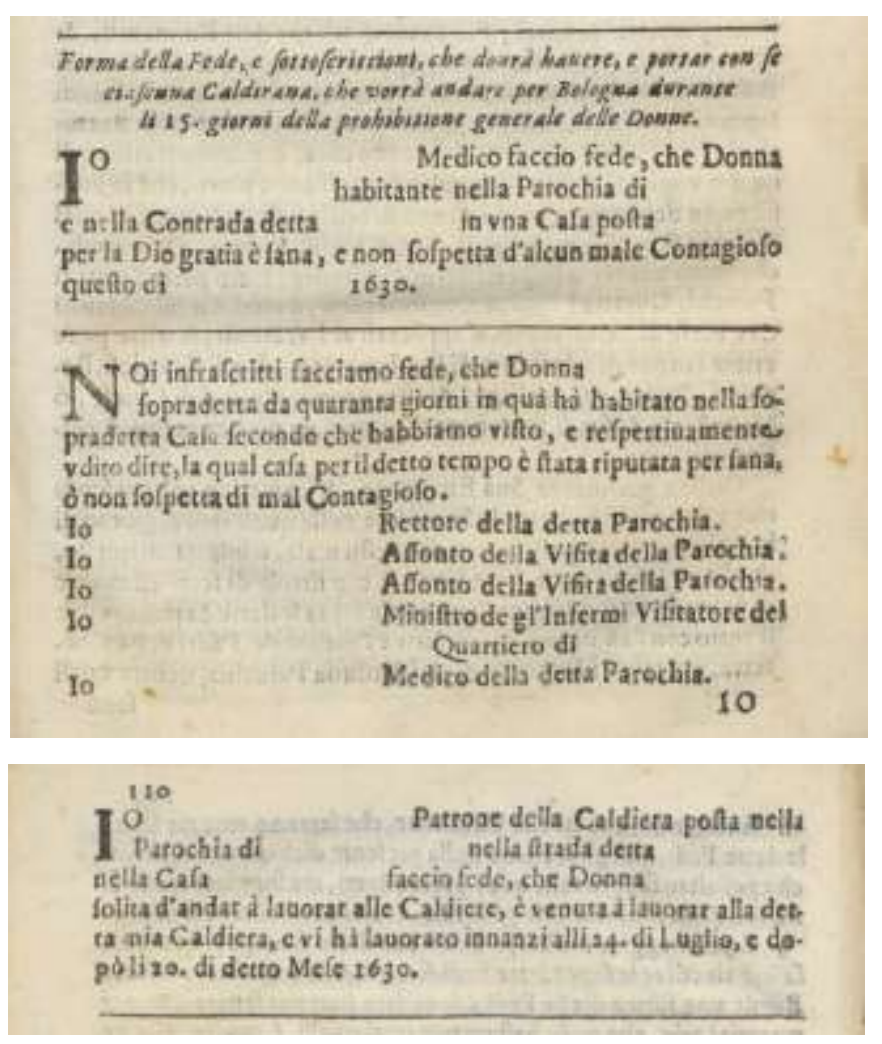

Figure 2 Fede di sanità (Donini 109-10).

Within a few days of the initial $25^{\text {th }}$ of July decree requiring women and children to remain at home, a new bando was released which expressed how the previous laws had been prejudicial against the Silk Arts in the city (Malpezzi et al. 99). The Bando e dichiarazione sul lavoro

${ }^{25}$ The total population estimate of Bologna in 1587 was 72,000 (Bellettini 48). 
delle caldirane, ovvero le donne che vanno a lavorare alle caldiere, an edict addressed to the female silk workers who worked with the cauldrons, published $27^{\text {th }}$ of July 1630 , made clear the need to support the silk industry, allowing women to travel to work in the silk mills. The new bando permitted women who worked as caldirane to obtain a fede (certificate of health) to continue to work as long as they had completed a period of quarantine or were not suspected of plague (Fig. 2). Women found without their fede would be subjected to penalties. Furthermore, women were commanded to take the shortest route when travelling to and from work and were informed not to make any stops or visit any house (100).

The bando and fede demonstrate the type of identification and classification of women into a set category, those who worked as a caldirana, with new rules and limitations to mobility. They highlight the importance of the silk industry in Bologna and the influence that profits and large industry had within governmental decision making. In this instance, the central authority determined the restrictions of mobility based on the city's economic needs. The parish authorities acted on these rules and determined which women fit within the classification of caldirane, determining her health based on instances of plague within her household. No less than five health officials of their parish had to sign the fede along with her employer.

Given the seasonal nature of the silk industry, it was essential over the summer months at the peak of the epidemic, that production continued. In particular, the women who made up the largest portion of the employees of the silk production were paramount in the continuation of the industry but also in the maintenance of their household economy which relied on this seasonal work. Entering a new classification, caldirane were permitted to leave their home to work but were prohibited to freely move throughout the city. No one classification authorized complete unimpeded access to the streets; yet, along with the caldirane, other occupational classifications offered women more maneuverability.

\section{Women and Work: Lazzaretti}

The largest impact made by women in the aid of the plague effort were from those who worked in the plague hospitals and convalescent homes. The lazzaretti in Bologna were religious houses converted into temporary hospitals and convalescence spaces. These structures all resided outside the walls of the ancient city in close proximity to each other, fortified with large iron gates and guarded around the clock (Moratti 12). The two main hospitals were the Convento di Santa Maria degli Angeli, known as "Angeli," dedicated to sick men, and the Convento della Santissima Annunziata, or simply "Annunziata," which housed sick women. These hospitals were under the authority of the director of the lazzaretti, Padre Orimbelli, whose offices resided in a monastery complex across the street from Annunziata. Women joined the large network of people who supplied the lazzaretti with food and wine (Orimbelli 135v), ${ }^{26}$ and were paid employees, assuming such duties as nurses, cleaners, and even a surgeon (Moratti 13). Textual sources reveal that at the peak of the epidemic women made up approximately $30-40 \%$ of the workforce in the two main plague hospitals. The largest portion of female employees were nurses, understandable given the strong legacy of female practitioners in Italy.

The medical system in Italy had long since acknowledged women's role in healthcare, although female healers were more recognized in the medieval period. Gianna Pomata and Rosemarie Foy have noted that the title "medicus" applied to "surgeons, barbers, and even women" in medieval Italy (Pomata and Foy 61-62). In Bologna, medieval records show that women were given the designation "medica" when they practiced healing arts (Pomata 121). Nonetheless, as the influence of elite physicians represented by Bologna's College of Medicine grew in the sixteenth-century, there was an increased partitioning of health practitioners within a hierarchical system which placed doctors at that top, and apothecaries and surgeons nearer the bottom, excluding women altogether (Pomata and Foy 62). Clear delineations between roles and responsibilities were enforced and licensing of all three positions came to fall under the purview of the college (63). Pomata notes that from late 1500 s until the latter part of the eighteenth-century, no women were listed as either doctors, apothecaries or surgeons licenced by the college (Pomata 121). The only roles that women undertook in an official capacity were as midwives and occasionally as suppliers of remedies for the treatment of female ailments when supervised by men (130). However, epidemics and war offered opportunities for unlicensed women to practice as healthcare workers, providing chances to break physical and social boundaries.

The importance of unlicensed practitioners during moments of crisis should not be underestimated. Roy Porter contends that while early modern doctors often resorted to

\footnotetext{
${ }^{26}$ Payments made to female vendors include: Signora Matriglia (Orimbelli 148r), Madonna Laura Cavazzoni, (156r-v, 159r-v), Madonna Ludovica (184).
} 
bloodletting and remedies with dangerous effects, women were the most significant of healers as they addressed their patients within the "context of individual life experiences", and with a focus on healthcare as a cooperative process between the sick and the healer (Porter 14-15, cited in Whaley 132). Furthermore, women, in particular nuns, were responsible for recipes and the pharmaceutical production of anti-plague remedies in early modern Italy (Strocchia 73). Due to the cost of many of the ingredients found in plague remedies, a do-it-yourself approach was adopted. As Sharon Strocchia has demonstrated, the popularity of homegrown treatments highlights how early modern Italians from all social backgrounds "proactively supplemented public health measures to increase their chances of survival" (79).

The regulations for confinement would have restricted unlicensed female healers from leaving their homes, even to visit people within their communities, but the lazzaretti offered a space in which to practice freely. Female practitioners, unlike doctors, were not mandated to serve and thus their motivations for employment were likely out of charity or desperation. Doctors were conscripted into service, but health officials had made concessions for doctors so that they could transfer their service altogether to someone else, such as a surgeon, by paying a fine of 50 scudi, the Papal currency of Bologna. Otherwise, they could perform their service without ever stepping inside the lazzaretti. Instead, the barber surgeons could collect information on each patient and report to the doctor, who would then prescribe treatment (Orimbelli 131v-132r). Therefore, the direct care of the sick fell to the barber surgeons and nurses.

The management of staff within the hospitals was hierarchical, with Orimbelli in command. Women traditionally held leaderships roles in the management of plague hospitals, as Stevens Crawshaw has shown in Venice, but these positions largely disappeared by the fifteenthcentury (Stevens Crawshaw, Plague Hospitals 125-26). In Bologna, no women are recorded to have worked in the offices of the hospital management. The only management position given to women were leadership roles within the Annunziata lazzaretto for women; two female head nurses took the responsibility to monitor 10 or 12 nurses under each. ${ }^{27}$ The hospitals necessitated a consistent influx of health practitioners in part due to the high mortality rate of staff (Moratti 30).

\footnotetext{
${ }^{27}$ Anonymous, A.S.V., Bologna, 282, f. 234 ss., cited in Brighetti 268-70.

${ }^{28}$ Anonymous, A.S.V., Bologna, 282, f. 290 r.v., cited in Brighetti 282. Letter dated $21^{\text {st }}$ of June, 1630 and written from Orimbelli's
}

At the opening of the lazzaretti in June 1630, Orimbelli's letters reveal a great need for nursing staff, ${ }^{28}$ and nurses were moved between the institutions according to need. ${ }^{29}$ Regardless of necessity, nurses were poorly viewed in the official narrative of the plague events. In Moratti's chronical of 1631, he accuses female nurses of having carnal relations with lazzaretti officials (30). The stereotype of the immoral female nurse was very present in this seventeenthcentury epidemic context. This bias could in part be based on the reliance on marginalised people to work in the hospital.

In times of crisis, necessity permitted convicts and prostitutes momentary escape from social barriers that normally kept them outside of regular society. It was a common practice for early modern cities managing plagues to offer reduced sentences or commuted sentences for prisoners in exchange for their service in the lazzaretti. Stevens Crawshaw has shown that entire prison sentences could be exchanged to serve as "pizzigamorti", those in charge of body removal in Venice (Stevens Crawshaw, Plague Hospitals 113). A record of employees in Bolognese lazzaretti from the 30th of December 1630 reveal that Casa della Mela had two male prisoners and a woman listed as "Domenica da Modona meretrice prigione", an imprisoned prostitute. $^{30}$

The plague presented down and out women, such as prostitutes, with extreme challenges. As Henderson has argued, during the plague of 1630-1 in Florence, the government took measures against prostitutes because they were perceived as "contributing to the sin for which God was punishing the city" (Henderson 240). Likewise, in Bologna prostitutes and homeless women were some of the first to be targeted by public policy. On the $1^{\text {st }}$ of July 1630, the Bando di divieto alle meretrici affinché non escono fuori dalle porte della città banned the activities of prostitutes and female beggars from exiting the city or from being found with a man (Malpezzi et al. 87). The closure of brothels brought unemployment for these women. Some women disregarded the regulations out of necessity, taking the risk of contracting the contagion with the potential punishment of prison time. The prejudice against prostitutes and homeless women was evident in these policies that categorized all women of the lowest social order as causes of contagion. The movement of these women was considered a threat to public health and breaking these laws resulted in a three-month prison sentence.

office in the Monastero de' Padri Gesuati, known today as the ExConvento delle Acque outside Porta San Mamolo.

${ }^{29}$ Anonymous, A.S.V., Bologna, 282, f. 269 r., cited in Brighetti 275.

${ }^{30}$ Anonymous, A.S.V., Bologna, 282, f. 215, cited in Brighetti, 280. 
Moratti's contemporary account of events indicates that prostitutes came to serve at Bologna's hospitals, although he writes that prostitutes were "persuaded to this service not from charity, but from greediness for profit, and to live better than in their homes" (30). His contemporary gaze on these women calls attention to the prejudice faced by prostitutes, who were regarded as corrupt and immoral people. He does not include similar judgments on the men who worked in the lazzaretti, despite a number of male ex-convicts who traded in prison sentences for hospital work. ${ }^{31}$ Instead, Moratti targets women who put their own lives at risk to serve their communities, women who likely had no other chances to find employment. More favourable contemporary accounts of prostitutes working in lazzaretti during early modern epidemics form part of conversion stories of those who permanently entered convent life (Henderson 206).

The personal stories of prostitutes that came to work in the lazzaretti in Bologna have all been lost save for one. A case of misconduct that was brought against a priest working in a plague hospital to the Bolognese courts records exprostitute, Susanna Ricci. Notary records show that Ricci worked in the San Giuseppe convalescent home for women, alongside the priest Bartolomeo Lena, who extorted Ricci along with others, forcing them to steal belongings from the sick. Of note, Ricci was named as a former prostitute who came to work in the lazzaretto as a barbiera (female barber surgeon) exclusively treating women. She dressed as a nun and pledged that, if she survived the plague, she would enter a religious order. ${ }^{32}$ The court case also revealed that Ricci was both courted and harassed by a number of men, from noble, merchant and religious backgrounds, during her time at the lazzaretto, but she never left. ${ }^{33}$ The plague year allowed her to gain temporary status under the category of barbiera, when otherwise she was banned from practicing her skills. Likewise, the epidemic provided previously excluded women a range of work opportunities. The complex story of female work in the hospitals is evident in primary sources that exist for three main snapshots of the plague: at the peak in July, in November as the situation began to improve, and in December when the majority of patients had exited.

Documents compiled on behalf of the Orimbelli's office on the $8^{\text {th }}$ of July 1630 record the names of all employees, along with their title at each of the hospitals at the height of the epidemic. ${ }^{34}$ In the house of the officials twenty-four men, and no women were working. In the Angeli lazzaretto, out of twenty-eight employees, eight were women, making up $29 \%$ of the employees. The Angeli records reveal that four women were called "infermiera" (nurse) and one had the role of "sotto infermiera" (under-nurse). Additionally, two women were listed as "bugadara" the title given to a laundress. One man is listed as a guard, and then nine additional male nurses are named, along with male apothecary, barber surgeons, and body carriers. ${ }^{35}$ Angeli had more male nurses than female but, contrary to Moratti's account which claimed that each gender was cared for by someone from their own sex, female nurses also treated male patients (Moratti 13).

Compared to the twenty-eight employees at Angeli, Annunziata, the largest hospital and dedicated to the care of women, boasted fifty-four. Of those, twenty-one were women, approximately $39 \%$ of the employees. The names and titles are listed in the textual source, recalling the roles adopted by women which consisted of eleven nurses, six titled "cuciniera" (female cook), three titled "dispensiera" who distributed remedies to the sick, and one wife of the watchman. ${ }^{36}$ In contrast, the male employees were two doctors, four barber surgeons, a watchman and his assistant, a dispenser and his assistant, house master, a "canevaro" custodian of the cellar, as well as three cooks, three scullery servants, a kitchen assistant, and apothecary, a doctors' servant, a keeper of the servants, seven "beccamorto" (gravediggers), a hole digger, and three "portatore da cocchietti", those who transported the sick from the city (277-28). Unlike the Angeli, no male nurses are listed, demonstrating that women were responsible for the direct care of other women in the women's lazzaretto. The doctors and barber surgeons were in smaller numbers than nurses, which could indicate that nurses took on more primary care.

Casa della Mela convalescent home had significantly less workers consisting of guards, a cook, a few assistants and one barber surgeon. Out of eleven employees, four were women including three kitchen assistants and the wife of the watchman (278). These initial records reveal how the strict divisions of labour was gendered with some crossover. The role of a laundress was solely for women. While doctors, surgeons, and body carriers were exclusively male. However, both men and women are listed as nurses, dispensers of medicine, and as cooks.

\footnotetext{
${ }^{34}$ Giovanni Salano and D. Hylario. Note de' ministri et Offitiali fuori fi S. Mamolo fatto il giorno 8 di luglio dal Padre D. Hylario Instante Giovanni Salano. A.S.V., Bologna, 282, f. 249 r. - 250r., and f. 414 r.- 416 r., cited in Brighetti 276-8.

${ }^{35}$ Ibid., cited in Brighetti 276-77.

${ }^{36}$ Salano and Hylario. A.S.V., Bologna, 282, f. 414 r.- 416 r., cited in Brighetti, 277-78.
} 
The subsequent bookkeeping records from Libro di dare, et avere provide a snapshot four months later on the $10^{\text {th }}$ of November 1630, with similar trends in employee data, although with a slight decrease in workers. A total of fortysix employees are registered in Annunziata. No doctors are recorded, only two apothecaries, along with two cooks and thirteen servants. Out of all employees, eight were women including one female cook, two laundresses, and five nurses. Four male nurses are noted along with the body carriers and a dispenser of medicine (Orimbelli 164v). The presence of male nurses in an exclusively female hospital illustrates that at a later stage of the epidemic, men also took direct care of women.

This record also exhibits the meaningful relationships formed between employees. At the bottom of the document, a note reads: "This is the entire family found presently in the Santissima Annunziata lazzaretto" (Orimbelli 164v, my translation).$^{37}$ The reference to these people belonging to part of a family demonstrates the strong bonds between those who came to serve in the lazzaretto in a period of crisis. The family bonds are also evident when looking at the other types of relationships between employees. For instance, a watchman along with his wife, titled "guardiana" (watchwoman), would commonly act as gatekeepers together, ${ }^{38}$ with the expectation that the family unit could remain intact. Employee records from Annunziata, Angeli, and Casa della Mela, confirm that women titled guardiana were present along with their watchmen husbands in all locations. Furthermore, in Casa della Mela, a cook and a "little girl her daughter" are listed, demonstrating how a mother could remain with her child and work in the hospital. ${ }^{39}$ These relationships show how the nuclear family was maintained even in one of the most dangerous places of the city.

The final snapshot of textual sources at the period of decline of the epidemic on the $30^{\text {th }}$ of December 1630 shows less employees, although these are still confined to gender specific roles. The only women recorded in the Annunziata lazzaretto are the wife of the watchman, four washers along with two on retainer, and a "cuciniera". In the Angeli lazzaretto, only four female washers are listed. ${ }^{40}$ Documents show further diminished occupancy in the main hospitals, Annunziata, Angeli, and Casa della Mela, as well as in the administrative offices. Annunziata had only nine reported

\footnotetext{
37 "Questa è tutta la Famiglia si ritrova presentemente al lazaretto della SSma Annunziata" (Orimbelli 164v).

${ }^{38}$ Anonymous, A.S.V., Bologna, 282, f. 265 r.v., cited in Brighetti 273.

${ }^{39}$ Orimbelli, 165r; Anonymous, A.S.V., Bologna, 282, f. 215, cited in Brighetti 279-80; Salano and Hylario. A.S.V., Bologna, 282, f. 249 r., cited in Brighetti 277-78.
}

employees compared to fifty-four recorded in July and the forty-six recorded in November. Of those only one woman, "una cuciniera vechia" (an old female cook) was reported. Once again, no women are recorded to have worked in the offices of the hospital director. Casa della Mela records the wife of the watchman, alongside "Isabetta cuciniera", two laundresses, and one imprisoned prostitute, likely carrying out her sentence in the lazzaretto. ${ }^{41}$

These textual sources reveal that women undertook duties as dispensers of medicines, as primary caregivers, and as leaders of other staff. These occupational categories excluded women from the quarantine restrictions and permitted them brief shifts in physical and social mobility. The convalescent homes and lazzaretti were places in which unlicensed female practitioners could be recognized and paid for their services in an era that otherwise ostracised women. In some cases, the female body that was previously marked for exclusion acquired new levels of freedom when women's social category temporarily changed meaning, such was the case when ex-prostitutes became infermiera or barbiera. The plague hospital offered marginalised women in particular clear avenues for temporary improvement to their social standing, but with great personal risk. Brothels were closed yet hospitals provided places to sleep, eat and earn. But mobility here was also limited. Although no longer confined to the home, women who worked in the lazzaretti were confined in new ways by the gated and guarded hospital structure.

\section{Conclusion}

The 1630-1 outbreak in Bologna is exemplary of the ways in which the female body was segmented and controlled under Italian early modern health policies in times of plague. The categorization of the female body as "abnormal" created an environment in which women were primary targets for health policies during epidemics, which separated healthy women from the public spaces of the city, confining them to their homes. Exceptions to these policies opened the door for women to enter new classifications with increased maneuverability. The example of Bologna has shown that access to mobility in periods of plague was contingent on exiting the category of "woman," as defined by the $25^{\text {th }}$ of July bando confining all women to their homes,

\footnotetext{
${ }^{40}$ Anonymous, A.S.V., Bologna, 282, f. 269 r., cited in Brighetti 274.

${ }^{41}$ Anonymous, A.S.V., Bologna, 282, f. 215, cited in Brighetti 27980 .
} 
and entering fresh categories under law formed from social or economic class and occupation. Classifications based on employment status and societal background, such as caldirane, infermiera, gentildonna, permitted more freedom, simultaneously introducing women to new categories of exclusion with varying degrees of mobility. Prostitutes and peasants, nurses and noble women, could each cross the boundaries of domestic confinement, but only to be confronted with new forms of containment.

These classifications permitted women maneuverability in the greatest disaster to hit Bologna in the seventeenth century. The dominant historical narrative on this event in Bologna has focused solely on the contribution of doctors and learned men while devaluing the variety of roles held by women. Those who volunteered for service in the plague hospitals were celebrated as part of a family of employees but have otherwise been negatively remembered in the contemporary narrative. The scarcity of visual sources has opened up fresh opportunities to journey through the rich textual material of the hospital and legal records, revealing the vital contributions made by women, especially women of lower classes, through work in local industry and in the lazzaretti. These documents have shone light on the agency and resilience of individual women in moments of crisis and have demonstrated that the ability to move, to travel, and to navigate the horrors of this event was deeply discriminative. Mobility was gendered, classist and conditional, issues that continue to be relevant in the twenty-first-century global pandemic in which we find ourselves today.

\section{Works Cited}

Anonymous, Archivio di Stato di Bologna, Torrone, 5783, c. 552r. Anonymous, Archivio Segreto Vaticano (A.S.V.), Bologna, 282, ff. 108-290 r.v., 1630-1.

Arbizzani, Carla et al. Bologna città della seta: macchine, tecniche, impianti produttivi nei secoli 16.-18. Istituto Aldini Valeriani, 1990.

Bellettini, Athos. La popolazione di Bologna dal secolo XV all'unificazione Italiana. Zanichelli, 1961.

Brighetti, Antonio. Bologna e la peste del 1630: Con documenti inediti dell'Archivio Segreto Vaticano. Gaggi, 1968.

Cipolla, Carlo M. Cristofano and the Plague: A Study in the History of Public Health in the Age of Galileo. Collins, 1973.

Cohn, Samuel. Cultures of Plague: Medical Thinking at the End of the Renaissance. Oxford University Press, 2012.

Donini, Girolamo. Raccolta di tutti li bandi: ordini, e provisioni fatte per la città di Bologna in tempo di contagio imminente, $e$ presente, li anni 1628, 1629, 1630, e 1631. Bologna: Girolamo Donini, 1631. Harvard Library Viewer. iiif.lib.harvard.edu/manifests/view/drs:7392101\$7i.

Franceschi, Franco. "Big Business for Firms and States: Silk Manufacturing in Renaissance Italy.” Business History
Review, vol. 94, no. 1, 2020, pp. 95-123. doi:10.1017/S0007680520000100.

Garzoni, Tommaso. La piazza universale di tutte le professioni del mondo. Giovanni Battista Somasco, 1586.

Giusberti, Fabio, and Francesca Roversi Monaco. "Economy and Demography." A Companion to Medieval and Renaissance Bologna, ed. Sarah Rubin Blanshei, Brill, 2017, pp. 154-84. doi: 10.1163/9789004355644.

Guerrini, Guido. I lazzaretti di Bologna durante la peste del seicento. Bologna: Tip. A. Brunelli, 1928.

Henderson, John. Florence Under Siege: Surviving Plague in an Early Modern City. Yale University Press, 2019. doi: 10.12987/yale/9780300196344.001.0001.

Iachomo, Pietro. Archivio Segreto Vaticano (A.S.V.). Bologna, 282, f. $121 \mathrm{r}$.

Malpezzi, Pietro, Marialuisa Lugaresi, and Bernardino Spada. I Bandi di Bernardino Spada durante la peste del 1630 in Bologna, ed. Pietro Malpezzi. Casanova, 2008.

Massey, Doreen B. Space, Place, and Gender. University of Minnesota Press, 1994.

Moratti, Pietro. Racconto de gli ordini e provisioni fatte ne' lazaretti in Bologna e suo contado in tempo del contagio dell'anno 1630. Clemente Ferroni, 1631.

Orimbelli, Angelo P. Libro di dare, et avere. Biblioteca Comunale Archiginnasio di Bologna, Manoscritto B.2195, (c. $17^{\text {th }}$ century).

Pastore, Alessandro. Crimine e giustizia in tempo di peste nell'Europa moderna. Laterza, 1991.

Pomata, Gianna. "Practicing between Earth and Heaven: Women Healers in Seventeenth-Century Bologna.” Dynamis, vol. 19, 1999, pp. 119-43.

Pomata, Gianna, and Rosemarie Foy. Contracting a Cure: Patients, Healers, and the Law in Early Modern Bologna. The Johns Hopkins University Press, 1998.

Poni, Carlo. "All'origine del sistema di fabbrica, tecnologia e organizzazione produttiva dei mulini da seta nell'italia settentrionale (sec. XVII-XVIII).” Rivista Storica Italiana, 1976, pp. 444-97.

--. "Misura contro misura: come il filo di seta divenne sottile e rotondo." Quaderni Storici, vol. 16, no. 47 (2), 1981, pp. 385422. JSTOR, www.jstor.org/stable/43777795.

--. "Tecnologie, organizzazione produttiva e divisione sessuale del lavoro. Il caso dei mulini da seta." Il lavoro delle donne, ed. Angela Groppi. Laterza, 1996, pp. 269-96.

Porter, Roy. "Quacks and Doctors". The Listener, 23 June 1983, pp. 14-16.

Righi, Laura. "Produzione di seta e trasferimenti tecnologici tra legislazione e frodi: Il caso di Bologna dal XIV al XVI secolo." Archivio Storico Italiano, vol. 174, no. 4 (650), 2016, pp. 639-68. JSTOR, www.jstor.org/stable/10.2307/26230114.

Salano, Giovanni and D. Hylario. Note de' ministri et Offitiali fuori fi S. Mamolo fatto il giorno 8 di luglio dal Padre D. Hylario Instante Giovanni Salano. Archivio Segreto Vaticano (A.S.V.)., Bologna, 282, f. 249 r. - 250r., and f. 414 r.-416 r.

Stevens Crawshaw, Jane. "Families, Medical Secrets and Public Health in Early Modern Venice." Renaissance Studies, vol. 28, no. 4, 2014, pp. 597-618. doi: 10.1111/rest.12081.

--. Plague Hospitals: Public Health for the City in Early Modern Venice. Routledge, 2016. doi: 10.4324/9781315600680. 
Strocchia, Sharon T. Forgotten Healers Women and the Pursuit of Health in Late Renaissance Italy. Harvard University Press, 2019. doi: 10.4159/9780674243446.

Terpstra, Nicholas. Cultures of Charity: Women, Politics, and the Reform of Poor Relief in Renaissance Italy. Harvard University Press, 2013. doi: 10.4159/harvard.9780674067929.

Tosi Brandi, Elena. "Il velo bolognese nei secoli XIV-XVI:

Produzione e tipologie." Il velo in area mediterranea fra storia e simbolo: Tardo medioevo-prima età moderna, ed. Maria Giuseppina Muzzarelli, Maria Grazia Nico Ottaviani, and Gabriella Zarri, Il mulino, 2014, pp. 289-305.

Whaley, Leigh Ann. Women and the Practice of Medical Care in Early Modern Europe, 1400-1800. Palgrave Macmillan, 2011. doi: 10.1057/9780230295179. 